\title{
DESIGN OF A ENVIRONMENTAL FRIENDLY HOUSE BASED ON THE LOCAL WISDOM OF THE BUGINES TRIBE IN SOUTH SULAWESI INDONESIA
}

\author{
MUHAMMAD ARDI, MITHEN LULLULANGI, BAKHRANI A. RAUF \& DAN FAIZAL AMIR
}

Lecturer of Fakultas Teknik Universitas Negeri Makassar

\begin{abstract}
The purpose of this research is to find the design of environmental friendly small, medium, and big type residential plans, consisting of a living room, family room, guest bedroom, master bedroom, dining room, kitchen, bathroom, toilet and placement of doors, based on the insight of the local wisdom of the Bugines Tribe. The research location is the Bone, Soppeng, and Wajo regencies of south Sulawesi in Indonesia.The three districts have strong local wisdom related to residential houses. The sample was chosen by the purposive sampling method, i.e., people who are familiar with the local wisdom, related to residential properties. The sample (the respondents) of each regency was set at 25 people, thus giving a total sample of 75 people. The variables are small, medium, and large dwelling plans, consisting of the location of the living room, family room, guest bedroom, family bedroom, dining room, kitchen, bathroom and toilet, and living room door based on the environmental insight and local wisdom of the Bugines tribe. Data collection was done, by conducting interviews. The analysis used was qualitative descriptive analysis. The results of the study are as follows: (1) The location of the living room for the small, medium and large type of house is in the front on the left, or right, or in the middle; (2) for or a small type of house there is no family room. The location of the family room for a medium and large house is in the middle, side or rear; (3) for the smaller type of house there is no guest bedroom. For medium and large type houses, the location of the guest bedroom is in the front, or the left or the right side; (4) the location of the dining room is in the middle and has close access to the kitchen; (5) the location of the kitchen is at the back and facing forward; (6) the location of the bathroom and toilet for the medium and large type of house, both for the main bedroom and children's bedroom are in the room; (7) for asmall type of house, the location of the bathroom and toilet for the master bedroom is in the room, while the children's bathroom is outside the room. Each bathroom and toilet have a connection with the outside air; (8) the living room door is located at the front and not directly facing the bedroom; (9) the guest bedroom door for medium and large type of houses is located opposite the living room and lacks access to the living rooms and other spaces; (10) the placement of the main bedroom door for small, medium and large type of houses is in the direction of the private bathroom door (inner bathroom), and not facing the bed.

KEYWORDS: Bugines, Environmental Insight, House of Residence \& Local Wisdom
\end{abstract}

Received: Aug 01, 2017; Accepted: Aug 21, 2017; Published: Sep 07, 2017; Paper Id.: IJEEFUSOCT20171

\section{INTRODUCTION}

Population growth has a direct impact on housing provision. The existence of residential developments in certain areas will change the ecosystem and the physical environment of the area. Therefore, what needs to be understood in building a residence is to utilize the environment as needed and maintain the environment in order to be sustainable (Law Number 32, The year 2009, on Environmental Protection and Management). The statement is in line with, what is proposed by Trainer (2011), who states that, in constructing buildings, natural resources are exploited as needed. Furthermore, Doxiadis (2003), underlines that, humans have needs such as space, air, 
temperature, etc., and for shelter and require residential buildings, as a means of social services.

Local wisdom is another form of environmental ethics, which is a set of knowledge gained, through the process and learning of a community group (Marfai, 2012). Local culture is a local wisdom, because it has proven its ability to survive until now. Local wisdom is an idea and values, with local views that are embedded and followed by members of the community (Moendardjito in Ayatrohaedi, 1986). The sustainable environment will form a good diversity in the ecosystem. Ecosystem diversity creates a diversity of life forms and cultural diversity (Shiva in Kuswartojo, 2005).

The development of residential houses in the form of housing, especially in South Sulawesi Province (the province inhabited by theologians tribe), the developers who provide homes for the Bugines tribe in Makassar, Bone, shopping, and Wajo, is less concerned with the local wisdom of the Bugines tribe as long as environmental aspects are sustainable (Survey July 2014 in some residential development). Furthermore, some residential development conducted by the Bugines community in Bone, Soppeng, and Wajo districts, in September 2015, was found to be not based on the local wisdom of the local area. The community tended to build their houses, based on their taste and financial ability. In addition, the public ignored environmental aspects, such as landfills, septic tank, sewerage and rainwater, and green open spaces. The phenomenon showed that, residential design that, combine local Bugines tribal wisdom and sustainable environmental aspects, are not yet available. Very few are concerned about sustainable culture and the environment.

The purpose of this research was, to find the design of the floor plan of small, medium and big houses, involving the living room, family room, guest bedroom, master bedroom, dining room, kitchen, bathroom and toilet, and door placement, based on the local wisdom of the Bugines Tribe, taking into consideration their environmental insight.

Various theories underlying this research, are based on Law No.4 of 1992, on Housing and Settlement, Sarwono in Budihardjo and Djoko (1999), basically say that, the house is a building that serves as a residence and is a means of enabling the family, to carry out their daily duties. Frick and Petra Widmer (2006), says that, the home is a residence that meets the requirements of a decent life.

Hadi (2001), states that, residential houses are part of a settlement that, has a human residence environment to live a life equipped with social, economic, cultural, and service infrastructure, that is, a sub-city substitute. To build environmentally sound homes, strategies are needed to accommodate human aspirations and wants, while maintaining a sustainable environment. (Korten, 2001; Kuswartojo, 2005).

Tasdyanto (2008), said that, the local wisdom and environmental wisdom are the ethics, norms, and behavior towards nature that, exist in a community. Hamzah (2013), said that, local wisdom is dynamic knowledge, developed in certain communities associated with nature and the surrounding culture that, serves as a basis for humans to interact with their environment. Sartini (2004) and Adyana (2012), have suggested that, local wisdom is a local advantage that, relies on the values, norms, ethics, knowledge, technology, and behavior that a traditional community and institutional group used to address life and life problems.

Marfai (2012), describes the characteristics of local wisdom as follows: (1) is able to survive outside cultures, (2) has the ability to accommodate elements of external culture, (3) has the ability to integrate elements of external cultures into indigenous cultures, (4) ) has the ability to control, and (5) isable to give direction to the development of culture. 


\section{RESEARCH METHODS}

This type of survey research is the location is Bone, Soppeng, and Wajo regencies, selected by the purposive sampling method. The three districts have strong local wisdom, related to residential houses. The sample consisted of people, who are familiar with local wisdom related to residence. The number of respondents was limited to 25 people in each district, making a total sample of 75 people. The variables are small, medium, and large dwelling plans, involving the location of the living room, family room, guest bedroom, family bedroom, dining room, kitchen, toilet, and the placement of the living room door, based on the local wisdom of the Bugines tribe. Data were collected, by conducting interviews. The analysis used was qualitative descriptive analysis.

\section{RESULTS AND DISCUSSIONS}

Based on interview transcripts, with members of the Bugines tribe, the following information was obtained.

\section{The Location of the Living Room}

The location of the living room in the design of the house plan, was based on the local wisdom of the Bugines tribe for small, medium, and large houses. It was in the front of the house, on the right side, or on the left side. The local wisdom of the Bugines tribe does not place the guests in the middle, or on the side of the house. This is due to several factors: (a) guests cannot see directly the position of the door of the main room, children's room, and other spaces; (b) a visitor with malicious intent may not plan to commit his crime; (c) the guest does not know the social interaction in the household; and (d) the guest cannot see the daily consumption of the family.

\section{The Location of the Family Room}

The living room, based on the local wisdom of theologian's tribe, for small type houses does not allow the existence of a family room, which connects the living room with the other rooms. In a medium-sized house, the family room can be placed adjacent to the dining room. For large types of houses, the family room can be placed in the middle, side, or the back. The placement of the family room is strongly influenced, by the size of the house. For small and medium type houses, the family room is not too important. However, the most important are the bedroom, kitchen and dining room.

\section{The Location of the Guest Bedroom}

The guest bedroom, based on the local wisdom of the Bugines tribe, should be located at the front of the house and should be placed on the left side, or right side of the house. This is so that, (a) a resident guest cannot know the family room, children's room, and other rooms, (b) overnight guests do not have direct contact with the living room, and (c) overnight guests have less opportunities, to interact with family members.

\section{The location of the Master Bedroom}

The master bedroom is based on local Bugines tribe wisdom, and is occupied by the father and mother. For small houses, the main bedroom located in the front next to the living room can also be placed at the back, with access to the living room and children's bedroom. For medium and large houses, the main bedroom in the center has access to the living room, children's bedroom, and other rooms. This placement enables (a) the father and mother have more control of the child's sleeping space, (b) the father and mother have the closest access to the living room, (c) the father and mother can easily interact with the whole room. 


\section{The Location of the Dining Room}

The location of the dining room, for a small type of house based, on the wisdom of the Bugines tribe, is at the back of the middle or rear side. For medium and large houses, the dining room is in the middle position behind the living room, or next to the living room and has the closest access to the kitchen. The dining room is positioned at the center, or on the side and has an adequate connection with the outside air has several factors: (a) the father and mother can easily access and interact with the dining room, (b) the child and other family members can easily reach it, (c) the dining room has good air circulation, (d) does not cause a sense of overheating during lunch or dinner activities.

\section{The Location of the Kitchen}

The kitchen, based on the local wisdom of the Bugines tribe, for small, medium, and large types of houses is located at the back, either in the middle or on the side. The kitchen is positioned facing forward. Such a position has a meaning: (a) when a mother or family member does a cooking activity, she can easily hear and see when a visitor arrives, (b) a cooking family member can easily hear and see when people with evilintententer the house, (c) the front-facing kitchen is the bearer of fortune, and (d) the front-facing kitchen holds all the specified fortune.

\section{The Location of the Bathroom and Toilet}

The location of the bathroom and toilet, based on the wisdom of the Bugines tribe, for a smaller type of house, can be positioned in the master bedroom (bathroom and lavatory and mother's toilet). Bathrooms and toilets for children and other family members, are placed at the side of the center of the house. For medium and large houses, bathrooms and toilets can be positioned in each bedroom (private bathroom and toilet), while a public toilet reserved, when there is a family event, can be positioned at the back. The bathroom and toilet should be in direct contact, with the outside air. The position of the bathroom and toilet (a) facilitate the father and mother to perform bathing and toilet activities without interacting with other rooms, (b) facilitate the child and other family members to do bathing and toilet activities without interacting with other rooms, (c) does not produce odors, and (d) has adequate air circulation.

\section{The Placement of the Living Room Door}

The placement of the living room door, is based on the design of the residence, based on the local wisdom of the Bugines tribe. It is good for small, medium, and large houses, to be located at the center of the front of the building. The placement of the door is not facing, directly into the bedroom, either the main bedroom or the bedroom of children and family members. This means that: (a) the living room door gives full discretion to anyone who will enter the house to access the living room easily, and (b) when there are things that are not desired then it will not be about the occupants of the room.

\section{The Placement of the Guest Bedroom Door}

The placement of the guest bedroom door, based on the design of the dwelling house, for the houses of medium and large types, is positioned facing the living room. It is intended that: (a) that guests staying in the living room interact adequately, (b) guests staying are not allowed to interact with the living room and dining room unless they are invited, and (c) the placement of the door is not face-to-face with the place of sleep.

\section{The Placement of the Main Bedroom Door}

The master bedroom should not be face-to-face, with the living room door. Based on the Bugines tribe house- 
based design, for medium and large types of houses, the main bedroom door placement is the same as the private bathroom door (inner bathroom), not face-to-face with the bed. It is intended that: (a) the father and the mother do not sit or lie on the bed whenever the activity outside the home (b) where any person who is intent to cause harm will not directly target the occupant of the room, (c) no physical bad things will be directed on the occupants of the room.

\section{The Placement of the Children's Room Door (Small Type House)}

Children's bedrooms should not be face-to-face, with the living room door. Based on the wisdom of the Bugines tribe, for a small house, the placement of the children's bedroom door, should not be facing directly to the bed. It is intended that: (a) the child shall, when engaged in an out-of-home activity, not sit or lie down on the bed, (b) where any person who is physically intent to cause harm will not be directly on the occupant's target, (c) no physical bad things will be directed on the occupants of the room.

\section{The Placement of the Children's Room Door (Medium and Big House)}

Children's bedrooms should not be face-to-face, with the living room door. Based on the Bugines tribe house, wisdom of the house design, for medium and large type houses, the children's bedroom door is placed in the same direction as the bathroom door (inner bathroom), not face-to-face with the bed. It is intended that: (a) the child shall, when engaged in an out-of-home activity, not sit or lie down on the bed, (b) where any person who is intent on causing physical harm will not be directly on the occupant's target, (c) no physical bad things will be directed on the occupants of the room.

\section{CONCLUSIONS}

- The location of the living room for small, medium and large type of houses, is in front on the left or right side, or in the middle.

- For the smallest type of house, there is no family room. The location of the family room, for a medium and large house is in the middle, side and rear.

- For the smallest type of house, there is no guest bedroom. For houses of medium and large types, the location of the guest bedroom, is on the front side of the left or right side.

- The location of the dining room is in the middle, and has the closest access to the kitchen. The location of the kitchen is in the back and facing forward.

- The location of the bathroom and toilet in a house of medium and large type, both for the main bedroom and children's room is in the room. For the smallest type of house, the location of the bathroom and toilet in the master bedroom, is in the room, while in the children's bathroom is outside the room. Each bathroom and toilet has a connection, with the outside air.

- The living room door is located on the front, and not facing directly to the bedroom.

- The guest bedroom door for medium and large house types is located opposite the living room and lacks access to the living room and other spaces.

- The placement of the main bedroom door for small, medium and large types of houses, with private bathroom door (indoor bathroom), and not face to face with the bed. 


\section{REFERENCES}

1. Adyana, P. 2012. Macapat Tembang Discourse as the Revealer of Cognition System and Local Ethnic Wisdom of Java. Publikasiilmiah.ums.ac.id. Volume 2. No. December 22, 2012.

2. Ayatrohaedi, 1986, Personality Culture Nation (local Genius), Jakarta: Pustaka Jaya.

3. Budiharjo, Eko \& Djoko Sujarto. 1999. Sustainable Cities. Bandung: Alumni.

4. Doxiadis, Constantinos A. 2003. An Introduction To The Science Of Human Settlements-Ekistics, London: Hutchinson.

5. Frick, Heinz \& Petra Widmer. 2006. The building, Shaping, Inhabiting. Yogyakarta: Canisius Publisher.

6. Hadi, Bambang S. 2001. Utilization of Aerial Photograph and Geographic Information System for evaluation of Quality Changes of Urban Neighborhood Environment (Study in Kecamatan Umbulharjo Kota Yogyakarta). Yogyakarta: Graduate Program of Gadjah Mada University.

7. Hadi, S.P. 2001. Environmental Dimensions of Development Planning. Yogyakarta: UGM Press.

8. Hamzah, M. 2013. Environmental Education, A Brief Overview of Pengatar. Bandung: Refika Aditama.

9. Korten, David C. 2001. Toward the 21st Century: Voluntary Measures and Global Agenda (translation). Jakarta: Yayasan Obor Indonesia.

10. Kuswartojo, Tjuk. 2005. Housing and Settlements in Indonesia. Efforts to Make Sustainable Livelihoods. Bandung: ITB.

11. Marfai. 2012. Introduction to Environmental Ethics and Local Wisdom. Yogyakarta: UGM Press.

12. Sartini. 2004. "Excavating Local Wisdom Archipelago as a Philosophy Study". Journal of Philosophy. Vol. 37 No. 2.

13. Tasdyanto (ed.). 2008. The wisdom of Indonesian Cultural Environment. Yogyakarta: Ministry of Environment.

14. Trainer, Ted. 2011. The Radical Implication of a Zero Growth Economy 1 (http://rwer.wordpress.com/2011/2011/09/06/rwerissue-57-Trainerl, accessed July 19, 2015).

15. Law of the Republic of Indonesia. No. 4 of 1992 on Housing and Settlements.

16. Law of the Republic of Indonesia. No. 32 The year 2009 on Environmental Protection and Management. 